\title{
MDM2 promoter polymorphism (rs2279744) and serum estrogen level are associated with increased risk of epithelial ovarian cancer: A case-control study
}

\author{
Sohil Takodara ${ }^{1}$, Sagar Dholariya ${ }^{2, *}$, Rashid Mir ${ }^{3}$, Alpana Saxena ${ }^{4}$ \\ ${ }^{1}$ Assistant Professor, Dept. of Biochemistry, Geetanjali Medical College \& Hospital, Udaipur, Rajasthan, ${ }^{2}$ Assistnat Professor, \\ Dept. of Biochemistry, R. D. Gardi Medical College \& C.R.G.H. Hospital, Ujjain, Madhya Pradesh, ${ }^{3}$ Assistant Professor, Dept. \\ of Medical Lab, Faculty of Applied Medical Sciences, University of Tabuk, Saudi Arabia, ${ }^{4}$ Professor, Dept. of Biochemistry, \\ Maulana Azad Medical College and Associated Hospitals, New Delhi, India
}

*Corresponding Author: Sagar Dholariya

Email: drsagar.dholariya@gmail.com

Received: $22^{\text {nd }}$ July, 2018

Accepted: $22^{\text {nd }}$ August, 2018

\begin{abstract}
Introduction: Epithelial ovarian cancer (EOC) is most common malignancy affecting Indian women. One of the transcriptional targets of p53 is human homolog of Murine Double Minute 2 Oncogene (MDM2) which is a crucial negative regulator of p53. Polymorphism in intronic promoter P2 region of MDM2 at position 309 increase binding affinity of specific protein 1, lead to over expression of MDM2 and deflation of p53 pathway. The objectives of study were to find effect of MDM2 SNP309 T>G polymorphism and serum estrogen level on risk of development of EOC and interaction between MDM2 SNP309 T>G and TP53 72 Arg>Pro polymorphism.

Materials and Methods: Eighty EOC cases and eighty age matched healthy controls were included in study. MDM2 SNP309 $\mathrm{T}>\mathrm{G}$ polymorphism was detected by ASO-PCR technique and serum estrogen levels were detected by chemiluminescence immunoassay.

Result: MDM2 SNP309 GG genotype was associated with significantly increased risk (OR: 2.86, 95\%, CI: 1.07-7.66; P=0.03) and early age onset $(\mathrm{P}=0.001)$ of EOC. Serum Estrogen was significantly $(\mathrm{P}<0.05)$ higher in cancer patients than controls. MDM2 SNP309 T>G and TP53 72Arg>Pro gene polymorphism act additively in developing ovarian cancer.

Conclusion: This study provides evidence that MDM2 SNP309 $\mathrm{T}>\mathrm{G}$ promoter polymorphism in association with the higher serum estrogen levels is associated with genetic susceptibility and early age onset of ovarian cancer.
\end{abstract}

Keywords: Epithelial ovarian cancer, MDM2, TP53, Estrogen.

\section{Introduction}

EOC is one of the most common malignancy affecting Indian women. ${ }^{1}$ It is the most lethal of all gynecologic malignancies accounting for $52 \%$ of all gynecological cancers related deaths. ${ }^{2}$ In early stage maximum patients are asymptomatic, and more than $75 \%$ cases are diagnosed at a late stage. ${ }^{3}$ It is most lethal gynecological malignancy due to late detection and ineffective treatment for late stage. ${ }^{4}$ So, it is necessary to disclose the molecular mechanism of ovarian cancer development which is useful to diagnose ovarian cancer at early stage.

It is well known that inherited mutations of BRCA1, BRCA2, MLH1 and MSH2 are more prone to develops familial Ovarian Cancer. ${ }^{5}$ But role of genetic factors in sporadic ovarian cancer yet not clarified. Previously studies reported that polymorphism in cancer susceptibility genes are predisposing risk factor for development of cancer. ${ }^{6,7}$ These types of studies trace the pathogenesis of cancer and can be used as a prognostic marker.

Exposure to endogenous or exogenous genetic insults may be a cause of carcinogenesis. ${ }^{8}$ But body has powerful protective mechanisms to fight against them. One of the mechanisms is by popularly known "guardian of the genome", p53- a tumor suppressor protein. ${ }^{9}$ One of the transcriptional targets of p53 is human homolog of MDM2 which is a crucial negative regulator of p53. It is located on chromosome 12q13-14 with genomic size of $34 \mathrm{~kb} .{ }^{10}$

In normal cell, intracellular p53 is strongly under being in command of of MDM2 by action of auto inhibitory loop of p53-MDM2. In which, p53 as a transcription factor stimulate transcription of MDM2 which bind to N-terminal of p53 and hinder p53 dependent transcription by E3 ubiquitin ligase activity and targeted to proteosomal degradation, thus keep the p53 at an unnoticeable level. ${ }^{11,12}$ Interruption in this auto inhibitory loop or hyper activity of MDM2 lead to additional inactivation of $\mathrm{p} 53$, which obliterate the cell cycle checkpoint control and cell become carcinogenic. ${ }^{13,14}$ MDM2 also induce carcinogenesis by directly bind to pRB result in availability of free EF2 which promote cell cycle progression. ${ }^{15,16}$ As a negative regulator of p53 and pRB pathway, MDM2 known as a 'master of regulator gene'. ${ }^{17}$

Thus it is clear that over expression of MDM2 lead to tumor development by inactivation of p53 pathway. There are so many factors which affect MDM2 level; one of these is a polymorphism in intronic promoter $\mathrm{P} 2$ region of MDM2 at position 309 (SNP309 T>G; rs2279744). This SNP accentuates binding affinity of transcription activator specific protein 1(sp1), result in over expression of MDM2 and subsequently attenuation 
of p53 pathway ${ }^{18}$ associate with susceptibility of certain type of cancers like bladder, ${ }^{19}$ head and neck, ${ }^{20}$ hepatocellular, ${ }^{21} \quad$ oral, ${ }^{22}$ pancreas, ${ }^{23}$ lung ${ }^{24}$ and endometrial. ${ }^{25}$ The MDM2 SNP309 G-allele correlated with younger age at tumor diagnosis in patients with $\mathrm{Li}$ Fraumeni syndrome ${ }^{26}$ and sporadic soft tissue sarcomas. ${ }^{27}$ Large numbers of studies presented on this polymorphism but results were inconsistent for increased cancer risk and early diagnosis of cancer among different tumor types and ethnic group. ${ }^{28,29}$ Since EOC is an estrogen linked it is essential to assess the relationship of serum estrogen level with the MDM2 polymorphism..$^{30}$ Based on above framework, we planned a hospital-based case-control study to find effect of MDM2 SNP309 T>G polymorphism with serum estrogen level, genetic susceptibility and clinicopathological features of EOC and its interaction with TP53 72Arg>Pro polymorphism.

\section{Materials and Methods}

Study Population: A hospital based case-control study was carried out in department of biochemistry and obstetrics and gynecology at Maulana Azad medical college and associated hospital, New Delhi. Eighty EOC cases and eighty age matched healthy controls were included in pilot study. Adjustment of cigarette smoking, ${ }^{31}$ alcohol consumption ${ }^{32}$ and BRCA gene mutation ${ }^{33}$ were done in all subjects of study. The study groups were undergone detailed history and clinical examination. International federation of gynecology and obstetrics surgical staging system (FIGO) staging of cancer was used for staging. Blood sampling and Evaluation of patients and blood sampling was done at the time of admission in hospital. All subjects were undergone written informed consent process. Study was approved by institutional ethical committee of Maulana Azad medical college, New Delhi.

\section{Selection Criteria of Patients}

Inclusion Criteria: Newly diagnosed, untreated cases and histopathologically confirmed cases of EOC were selected for study.

Exclusion Criteria: Patients with a history of previous cancer or metastasized cancer from any other organs were excluded from this study.

Sample Collection: Total $5 \mathrm{ml}$ of peripheral blood was collected in EDTA tube and plain tube after confirmed diagnosis. Whole blood in EDTA tube was used for genotyping. Plain tube was centrifuged at $2000 \mathrm{rpm}$ for 20 minutes to separate serum and serum was used to estimate estrogen level. Blood samples were also collected from healthy female volunteers as controls.

Serum Estrogen Measurement: The serum estrogen was measured by electrochemiluminescence immunoassay method using elecsys E2 kit modified to ELECSYS 2010 (Roche diagnostics).
DNA Extraction: DNAsure ${ }^{\circledR}$ blood mini kit (Genetix, India) was used to separate DNA from blood sample. It was done according to manufacturer's instruction.

Genotyping of MDM2 SNP309 T>G Polymorphism: MDM2 SNP309 T>G genotypes were analyzed using ASO-PCR. Primer used for SNP309 T allele were F, 5'GGATTT CGGACGGCTCTC-3' and R, 5'TCCGGACCTCCCGCGCCGA-3', which produce $121 \mathrm{bp}$ fragment. Primer used for SNP309 G allele were F, 5'-GTTTTGTTGGACTGGGGCTA-3' and R, 5'ATCCGGACCTCCCGCGCCGC-3', which produce $168 \mathrm{bp}$ fragment. The amplification was carried out in total 25 ul reaction mixture. Composition of reaction mixture are as follows: $0.25 \mathrm{ul}$ of $25 \mathrm{pmol}$ each primer, $2.5 \mathrm{ul} 10 \mathrm{mM}$ dNTPs, 5 ul of $20 \mathrm{ng}$ template DNA, 0.3 ul of $5 \mathrm{U} / \mathrm{ul}$ Taq polymerase with $2.5 \mathrm{ul}$ of $10 \mathrm{X}$ Taq Buffer, 1.5 ul of $20 \mathrm{mM} \mathrm{MgCl} 2$. The amplification conditions were as follows: Initial denaturation at $95^{\circ} \mathrm{C}$ for $5 \mathrm{~min} ; 35$ annealing cycles at $95^{\circ} \mathrm{C}$ for $45 \mathrm{~s}, 60^{\circ} \mathrm{C}$ for $30 \mathrm{~s}$ and $72^{\circ} \mathrm{C}$ for $30 \mathrm{~s}$, extension step at $72^{\circ} \mathrm{C}$ for $5 \mathrm{~min}$. PCR products were visualized on ethidium bromide stained 2\% agarose gel.(Fig. 1) To know specificity of genotyping, fifteen samples were selected for repeated genotype assay. Results of repeated assay were $100 \%$ matched with previous assay.

\section{Statistical Analysis}

SPSS software version 16.0 was used for statistical analysis. Distribution of genotype and clinicopathological features were done by fisher exact/ Chi-square test. Comparison of mean was done by oneway ANOVA and Student's independent T test. Odd ratio and 95\% CIs were used to find association between polymorphism and occurrence of EOC. Chisquare hardy-weinberg equilibrium test was used for evaluating allele frequencies. ${ }^{34} \mathrm{~A}$ more than additive interaction in logistic regression model ${ }^{35}$ was used to find interaction between gene. P-value $<0.05$ was considered statistically significant.

\section{Results}

Baseline Characteristics of Subjects: EOC patients were categorized in two groups $>40$ years $(62.5 \%)$ and $\leq 40$ years $(37.5 \%)$, to find out effect of polymorphism on beginning of sporadic ovarian cancer. ${ }^{36}$ Cases were further categorized in to FIGO staging, histopathologically types and grades. Most of cases had stage III $(50 \%)$ followed by stage IV $(25 \%)$, stage I $(12.5 \%)$, stage II (12.5\%). Most of cases had mucinous $(50 \%)$ followed by serous $(42.5 \%)$, endometroid $(3.75 \%)$ and clear cell adenocarcinoma (3.75\%). Most of cases had moderately differentiated $(65 \%)$ followed by well differentiated $(25 \%)$, poorly differentiated $(10 \%)$ grading. There were no three or two diagnosis of ovarian/breast cancer in family of EOC cases. ${ }^{36}$

MDM2 SNP309 T>G Genotype Distribution: A significant different of genotype were found between cases and controls $(\mathrm{P}<0.001)$. Proportion of MDM2 
SNP309 T>G polymorphic forms were TT, 30\%; TG, $62.5 \%$; GG, $10 \%$ in controls. (Table 1 )

$38.75 \%$; GG, $31.25 \%$ in cases and TT, $27.5 \%$; TG,

Table 1: Distribution of MDM2 SNP309 T $>$ G genotypes in cases and controls

\begin{tabular}{|l|c|c|c|c|c|}
\hline \multicolumn{1}{|c|}{$\begin{array}{c}\text { MDM2 SNP309 } \\
\text { T>G Genotype }\end{array}$} & $\begin{array}{c}\text { TT } \\
\mathbf{n} /(\mathbf{\%})\end{array}$ & $\begin{array}{c}\text { TG } \\
\mathbf{n} /(\mathbf{\%})\end{array}$ & $\begin{array}{c}\text { GG } \\
\mathbf{n} /(\mathbf{\%})\end{array}$ & $\begin{array}{c}\text { T allele } \\
\text { frequency }\end{array}$ & $\begin{array}{c}\text { G allele } \\
\text { frequency }\end{array}$ \\
\hline Cases & $24(30)$ & $31(38.75)$ & $25(31.25)$ & 0.493 & 0.507 \\
\hline Controls & $22(27.5)$ & $50(62.5)$ & $08(10)$ & 0.587 & 0.413 \\
\hline
\end{tabular}

Chi-Square:13.30, df:2, $\mathrm{P}<0.001$

Above result showed that $\mathrm{TG}$ genotype more frequent in cases and controls. When we take a TT allele as a reference, odds ratio of TG vs. TT was $0.56(0.27-1.18)$ and GG vs. TT was 2.86(1.07-7.66). It showed that those patients expressed MDM2 GG allele had increased risk of EOC compared with those expressed MDM2 TT and TG allele. (Table 2)

Table 2: Odd ratio of MDM2 SNP309 T $>$ G among cases and controls

\begin{tabular}{|l|c|c|c|c|}
\hline $\begin{array}{c}\text { Genotype MDM2 } \\
\text { SNP309 T>G }\end{array}$ & $\begin{array}{c}\text { Cases } \\
\mathbf{n}(\%)\end{array}$ & $\begin{array}{c}\text { Controls } \\
\mathbf{n}(\boldsymbol{\%})\end{array}$ & $\begin{array}{c}\text { OR } \\
(\mathbf{9 5 \%} \mathbf{C I})\end{array}$ & p-value \\
\hline TT & $24(30)$ & $22(27.5)$ & $1(\mathrm{ref})$ & \\
\hline TG & $31(38.75)$ & $50(62.5)$ & $0.56(0.27-1.18)$ & 0.12 \\
\hline GG & $25(31.25)$ & $8(10)$ & $2.86(1.07-7.66)$ & 0.03 \\
\hline TG + GG & $56(70)$ & $58(72.5)$ & $0.88(0.44-1.75)$ & 0.7 \\
\hline
\end{tabular}

$* \mathrm{OR}$ and $95 \% \mathrm{CI}$ were calculated by unconditional logistic regression

Serum Estrogen Level in Different Genotype of MDM2 SNP309: Serum estrogen was significantly higher in EOC patients as compared to controls and also higher in reproductive age group as compared to post-menopausal group. (Table 3) Serum estrogen level was higher in those patients who expressed GG allele as compared to TG and TT allele in reproductive and post menopausal group in EOC patients. But it was significant high only in reproductive age group of EOC patients. (Table 4)

Table 3: Mean serum estrogen level in cases and controls according to menopausal status

*Student's unpaired t-test

\begin{tabular}{|l|c|c|c|}
\hline $\begin{array}{c}\text { Serum estrogen level } \\
(\text { Mean } \pm \text { SD) } \mathbf{~ p g} / \mathbf{m l}\end{array}$ & $\begin{array}{c}\text { Cases } \\
\mathbf{n}=\mathbf{8 0}\end{array}$ & $\begin{array}{c}\text { Controls } \\
\mathbf{n}=\mathbf{8 0}\end{array}$ & P value* \\
\hline Reproductive age group & $42.90 \pm 6.20$ & $20.50 \pm 5.72$ & $<0.05$ \\
\hline Post menopausal group & $30 \pm 5.90$ & $15.76 \pm 4.32$ & $<0.05$ \\
\hline
\end{tabular}

Table 4: Mean serum estrogen in different genotype of MDM2 SNP309 T>G polymorphism in EOC

*One-way ANOVA test

\begin{tabular}{|c|c|c|c|c|}
\hline $\begin{array}{c}\text { Serum Estrogen level } \\
\text { (Mean } \pm \text { SD) } \mathbf{~ p g} / \mathbf{m l}\end{array}$ & TT & TG & GG & P value* \\
\hline Reproductive age group & $39.38 \pm 5.56$ & $44.02 \pm 3.67$ & $45.62 \pm 4.72$ & $<0.05$ \\
\hline Post menopausal group & $27.93 \pm 2.22$ & $29.83 \pm 1.80$ & $28.53 \pm 4.20$ & 0.1 \\
\hline
\end{tabular}

FIGO staging, histopathological types and grade had no association with MDM2 SNP309 $\mathrm{T}>\mathrm{G}$ polymorphism in EOC. (Table 5)
Association MDM2 SNP309 T>G Polymorphism with Clinicopathological Features in EOC: Among ovarian cancer patients, the mean age of onset of cancer for TT, TG and GG genotypes of MDM2 SNP309 were 48(range 26-80), 43(range 20-60) and 36.25(range 2155) years old respectively. In $\leq 40$ years, group GG genotype and in $>40$ years, TT genotype was found to be more prevalent $(53.3 \%$ and $56 \%$ respectively). A significant association was found between early age onset of EOC and MDM2 SNP309 $\mathrm{T}>\mathrm{G}$ polymorphism. So above result showed that GG genotype was associated with early onset of EOC compared to TG and TT genotype. (Table 5) 
Table 5: Association between MDM2 SNP309 T>G polymorphism with clinicopathological features in EOC

\begin{tabular}{|c|c|c|c|c|c|c|c|c|}
\hline Variants & $\begin{array}{c}\text { TT } \\
\text { n }(\%)\end{array}$ & $\begin{array}{c}\text { TG } \\
\mathbf{n}(\%)\end{array}$ & $\begin{array}{c}\text { GG } \\
\mathbf{n}(\%)\end{array}$ & T allele & G allele & $\begin{array}{c}\text { Fisher } \\
\text { Exact/ Chi- } \\
\text { Square } \\
\end{array}$ & df & $\begin{array}{c}\text { p- } \\
\text { value }\end{array}$ \\
\hline \multicolumn{9}{|l|}{ Age } \\
\hline$\leq 40$ years & $8(26.7)$ & $6(20)$ & $16(53.3)$ & 0.36 & 0.64 & 12.77 & 2 & 0.001 \\
\hline$>40$ years & $28(56.0)$ & $14(28.0)$ & $8(16.0)$ & 0.70 & 0.30 & & & \\
\hline \multicolumn{9}{|l|}{ Menopausal Status } \\
\hline Reproductive age & $10(31.3)$ & $7(21.8)$ & $15(46.9)$ & 0.42 & 0.58 & 8.89 & 2 & 0.01 \\
\hline Menopausal & $27(56.3)$ & $13(27.0)$ & $8(16.7)$ & 0.69 & 0.31 & & & \\
\hline \multicolumn{9}{|l|}{ Stage } \\
\hline Early(I \& II) & $5(25.0)$ & $5(25.0)$ & $10(50.0)$ & 0.37 & 0.63 & 5.14 & 2 & 0.07 \\
\hline Late(II \& IV) & $30(50.0)$ & $15(25.0)$ & $15(25.0)$ & 0.63 & 0.37 & & & \\
\hline \multicolumn{9}{|l|}{ Histopathology } \\
\hline Mucinous & $15(37.5)$ & $11(27.5)$ & $14(35.0)$ & 0.51 & 0.48 & 0.37 & 6 & 0.99 \\
\hline Serous & $13(38.2)$ & $11(32.4)$ & $10(29.4)$ & 0.58 & 0.42 & & & \\
\hline Endometroid & $1(33.3)$ & $1(33.4)$ & $1(33.3)$ & 0.50 & 0.50 & & & \\
\hline Clear Cell & $1(33.3)$ & $1(33.4)$ & 1(33.3) & 0.50 & 0.50 & & & \\
\hline \multicolumn{9}{|l|}{\begin{tabular}{|l|} 
Grade \\
\end{tabular}} \\
\hline Well Differentiated & $10(50.0)$ & $7(35.0)$ & $3(15)$ & 0.67 & 0.33 & 6.32 & 4 & 0.27 \\
\hline Moderately differentiated & $18(34.6)$ & $13(25.0)$ & $21(40.4)$ & 0.47 & 0.53 & & & \\
\hline Poorly Differentiated & $5(62.5)$ & $2(25)$ & $1(12.5)$ & 0.75 & 0.25 & & & \\
\hline
\end{tabular}

MDM2 SNP309 T>G and TP53 Arg72Pro Polymorphism Interaction: We further analyzed whether there is an interaction between MDM2 SNP309 $\mathrm{T}>\mathrm{G}$ and TP53 Arg72Pro polymorphism in risk of development of EOC. The data showed that patients who expressed the MDM2 GG genotype were also more likely to carry the TP53codon 72Pro/Pro genotype than controls compared to TT and TG genotype $(11.3 \% \mathrm{Vs} 2.5 \%, \mathrm{P}=0.04)$. The presence of one MDM2 SNP309 GG genotype, but not one TP53 codon 72 Pro/Pro genotype, were associated with an increased risk of $\mathrm{EOC}(\mathrm{OR}=2.86, \quad \mathrm{CI}=1.07-7.66)$, compared to the lack of such genotype. However, the presence of both MDM2 SNP309 GG and TP53 72Pro/Pro genotypes was found to increased risk of EOC $(\mathrm{OR}=8.2, \mathrm{C} 1=1.32-51.26, \mathrm{P}=0.04)$ compared to those who lacked both genotypes. It indicates more than additive interaction between the MDM2 SNP309 GG and TP53 codon 72Pro/Pro genotype. (Table 6)

Table 6: Interaction between MDM2 SNP309 T>G and TP53 Arg72Pro polymorphisms in EOC

\begin{tabular}{|c|c|c|c|c|c|}
\hline \multicolumn{2}{|c|}{ Genotype } & \multirow[b]{2}{*}{$\begin{array}{l}\text { Cases } \\
\text { n (\%) }\end{array}$} & \multirow{2}{*}{$\begin{array}{c}\text { Controls } \\
\text { n }(\%)\end{array}$} & \multirow{2}{*}{$\begin{array}{c}\text { OR* } \\
(95 \% \text { CI })\end{array}$} & \multirow[t]{2}{*}{ P value } \\
\hline $\begin{array}{c}\text { MDM2 SNP309 } \\
\text { T>G }\end{array}$ & TP53 Arg72Pro & & & & \\
\hline \multirow[t]{3}{*}{ TT } & Arg/Arg & $6(7.5)$ & $11(13.7)$ & 1 (ref.) & \\
\hline & Arg/Pro & $15(18.7)$ & $9(11.3)$ & $3.0(0.83-11.13)$ & 0.16 \\
\hline & Pro/Pro & $3(3.8)$ & $2(2.5)$ & $2.7(0.35-21.13)$ & 0.63 \\
\hline \multirow[t]{3}{*}{ TG } & Arg/Arg & $13(16.3)$ & $36(45.0)$ & $0.6(0.20-2.15)$ & 0.70 \\
\hline & Arg/Pro & $15(18.7)$ & $12(15.0)$ & $2.2(0.64-8.44)$ & 0.31 \\
\hline & Pro/Pro & $3(3.75)$ & $2(2.5)$ & $2.7(0.35-21.30)$ & 0.63 \\
\hline \multirow[t]{3}{*}{ GG } & Arg/Arg & $6(7.4)$ & $2(2.5)$ & $5.5(0.83-36.19)$ & 0.15 \\
\hline & Arg/Pro & $10(12.5)$ & $4(5.0)$ & $4.5(0.99-21.11)$ & 0.10 \\
\hline & Pro/Pro & $9(11.3)$ & $2(2.5)$ & $8.2(1.32-51.26)$ & 0.04 \\
\hline
\end{tabular}

*Data analyzed by unconditional logistic regression.

\section{Discussion}

We aimed at studying the occurrence of MDM2 SNP309 $\mathrm{T}>\mathrm{G}$ gene polymorphism in introns 1 in cases of EOC and compared with normal healthy controls as a pilot study in Indian population. In our study, the odds ratio for GG vs.TT genotype in ovarian cancer was 2.86 (1.07-7.66), which was significant.
We found a high GG frequency $(53.3 \%)$ in women diagnosed at $\leq 40$ years and a much lower frequency $(16 \%)$ in women diagnosed at years of age $>40$ years. Early age onset (36.25 years) of EOC was fond in GG genotype compared to TG and TT genotype (43 and 48 years respectively). This observation is similar to study performed by Bartel et al. ${ }^{37}$ They reported that an 8.5 - 
year earlier diagnosis in GG and TG as compared to TT carriers in ovarian cancer patients.

MDM2 SNP309 GG genotype was associate with early age of onset of EOC which may be due to active estrogen signaling in premenopausal EOC women (Serum Estrogen $=45.62 \pm 4.72$ ) result in MDM2 overexpression. Thus more active estrogen signaling in premenopausal as compared to postmenopausal EOC women (Serum Estrogen $=28.53 \pm 4.20)$ may be a crucial factor to initiate MDM2 mediated tumorigenesis process in premenopausal women.

Our result is biologically acceptable and supports the previously reported observation. ${ }^{38,39} \mathrm{We}$ hypothesize that the homozygous GG variant of MDM2 SNP309 weakens wild-type p53 activity by increasing MDM2 levels. Estrogen signaling also determines level of MDM2 because of closeness of estrogen binding site to SNP309 in MDM2 promoter region. MDM2 SNP309 $\mathrm{G}$ allele along with high estrogen further increase MDM2 expression in EOC. It may be due to direct interaction of transcription factor spl with estrogen receptor in MDM2 promoter region. So high serum estrogen level in GG genotype associated with increased risk of ovarian cancer. ${ }^{38}$
MDM2 over expression or amplification of MDM2 has been frequently observed in many human cancer types, including ovarian cancer. Two recent reports have demonstrated that the G-allele of SNP309 and somatic p53 mutations are associated with an earlier age of onset of ovarian cancer patients. ${ }^{37,39}$

MDM2 not only interact with p53, but it also interacts with other tumor suppression protein like $\mathrm{Rb},{ }^{15}$ p $73^{40}$ and p14/p $19^{41}$ which might be contributing factor for carcinogenesis. This polymorphic site located near to element believed to direct the intronic TP53-response promoter activity of the gene, lead to increased levels of MDM2 RNA and protein in an in vitro functional assay. Higher promoter activity of MDM2 SNP309 GG variant increases the binding affinity of sp1 to the promoter region of MDM2. ${ }^{42}$ So GG variant express more MDM2 as compared to TT and TG genotype, result in more attenuation of p53 tumor suppression response and to end with carcinogenesis. Thus individuals with GG genotype may be a more susceptible to develop EOC. We found more than additive gene-gene interaction between MDM2 SNP309 GG and TP53 72Pro/Pro genotype for risk of developing Ovarian Cancer.

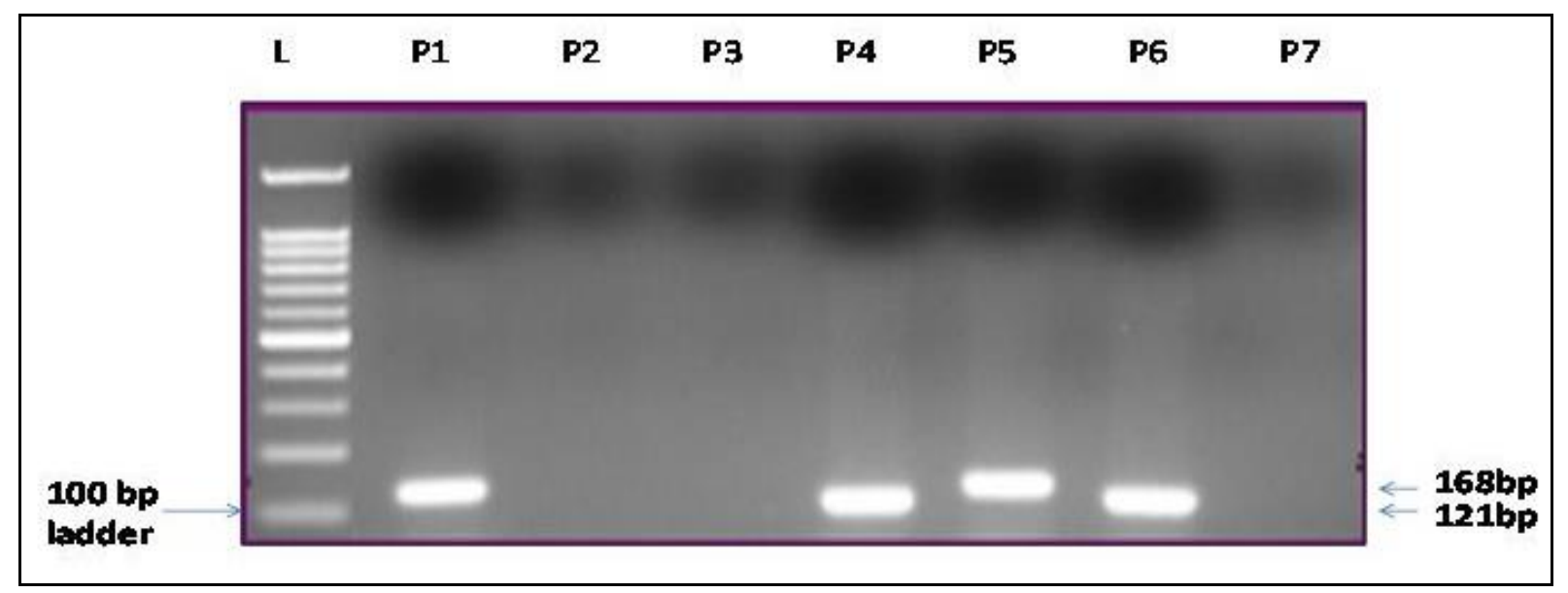

Fig. 1: Agarose gel electrophoresis band pattern of MDM2 SNP309 T and G allele after ASO-PCR (Lane: P1, P4, P6-positive for $T$ allele and $P 5$ - positive for $G$ allele)

\section{Limitation}

We performed pilot study on smaller sample size. Study should involve larger sample size to validate the results.

\section{Conclusion}

MDM2 SNP309 $\mathrm{T}>\mathrm{G}$ promoter polymorphism in association with the higher serum estrogen levels is associated with potential genetic susceptibility and early age onset of EOC in north Indian population. Interaction between MDM2 SNP309 $\mathrm{T}>\mathrm{G}$ and TP53 Arg72Pro was more than additive in developing EOC.

\section{Acknowledgements}

We would like to thank Dr. Nita Khurana for evaluating histopathology of ovarian cancer in this study.

Conflict of Interest: Authors have no conflict of interest to declare

Funding: This research received no specific grant from any funding agency 


\section{References}

1. Murthy NS, Shalini S, Suman G, Pruthvish S, Mathew A. Changing Trends in Incidence of Ovarian Cancer- the Indian Scenario. Asian Pac J Cancer Prev. 2009; 10:1025-30.

2. Jemal AR, Ward E, Hao Y, Xu J, Thun MJ. Cancer statistics. CA Cancer J Clin. 2009;59:225-49.

3. Brandon JDR, Gupta S, Dada R, Safi J, Michener C, Agarwal A. Potential Markers for Detection and Monitoring of Ovarian Cancer. J Oncol. 2011;2011:1-17.

4. Akahira J, Yoshikawa H, Shimizu Y. Prognostic factors of stage IV epithelial Ovarian Cancer: a multicenter retrospective study. Gynecol Oncol. 2001;81:398-403.

5. King MC, Marks JH, Mandell JB. New York Breast Cancer Study Group. Breast and Ovarian cancer risks due to inherited mutation in BRCA1 and BRCA2. Science. 2003;302:643-6.

6. Ueda M, Hung YC, Terai Y. Glutathione S-transferase GSTM1, GSTT1 and p53 codon 72 polymorphisms in human tumor cells. Hum Cell. 2003;16:241-51.

7. Ueda M, Toji E, Nunobiki O. Germline polymorphism of cancer susceptibility genes in gynecologic cancer. Hum. 2008;21:95-104.

8. Hussain SP, Harris CC. Molecular epidemiology and carcinogenesis: endogenous and exogenous carcinogens. Mutat Res. 2000;462:311-22.

9. Levine AJ. p53, the cellular gatekeeper for growth and division. Cell. 1997;88:323-31.

10. Kubbutat MH, Jones SN, Vousden KH. Regulation of p53 stability by Mdm2. Nature. 1997;387:299-303.

11. Haupt Y, Maya R, Kazaz A, Oren M. Mdm2 promotes the rapid degradation of p53. Nature. 1997;387:296-9.

12. Honda R, Tanaka H, Yasuda H. Oncoprotein MDM2 is a ubiquitin ligase $\mathrm{E} 3$ for tumor suppressor p53. FEBS Lett. 1997;420:25-7.

13. Momand J, Zambetti GP, Olson DC, George D, Levine AJ. The $\mathrm{mdm} 2$ oncogene product form a complex with the $\mathrm{p} 53$ protein and inhibit $\mathrm{p} 53$ mediated transactivation. Cell. 1992;69:1237-45.

14. Chen J, Wu X, Lin A. Mdm2 inhibits the G1 arrest and apoptosis function of p53 tumor suppressor protein. $\mathrm{Mol}$ Cell Biol. 1996;16:2445-52.

15. Xiao ZX, Chen J, Levine AJ, Modjtahedi N, Xing J, Sellers WR, et al. Interaction between the retinoblastoma protein and the oncoprotein MDM2. Nature. 1995;375:694-8.

16. Martin K, Trouche D, Hagemeier C, Sorensen TS, La Thangue NB, Kouzarides T. Stimulation of E2F1/DP1 transcriptional activity by MDM2 oncoprotein. Nature. 1995;375:691-4.

17. Knappskog S, Lonning PE. Effects of the MDM2 promoter SNP285 and SNP309 on Sp1 transcription factor binding and cancer risk. Transcription. 2011;2:207-10

18. Bond GL, Hu W, Bond EE, Robins H, Lutzker SG, Arva $\mathrm{NC}$, et al. A single nucleotide polymorphism in the MDM2 promoter attenuates the p53 tumor suppressor pathway and accelerates tumor formation in humans. Cell. 2004;119:591-602.

19. Sanchez-Carbayo M, Socci ND, Kirchoff T, Erill N, Offit $\mathrm{K}$, Bochner $\mathrm{BH}$, et al. A polymorphism in HDM2 (SNP309) associates with early onset in superficial tumors, TP53 mutations and poor outcome in invasive bladder cancer. Clin Cancer Res. 2007;13:3215-20.

20. Nakashima M, Kondo S, Shimizu Y, Wakisaka N, Murono S, Furukawa M, et al. Impact of MDM2 single nucleotide polymorphism on tumor onset in head and neck squamous cell carcinoma. Acta Otolaryngol. 2008;128:808-13.

21. Yoon YJ, Chang HY, Ahn SH, Kim JK, Park YK, Kang DR, et al. MDM2 and p53 polymorphisms are associated with the development of hepatocellular carcinoma in patients with chronic hepatitis B virus infection. Carcinogenesis. 2008;29:1192-6.

22. Huang SF, Chen IH, Liao CT, Wang HM, Liou SH, Hsieh LL. Combined effects of MDM2 SNP 309 and p53 mutation on oral squamous cell carcinomas associated with areca quid chewing. Oral Oncol. 2009;45:16-22.

23. Grochola LF, Müller TH, Bond GL, Taubert H, Udelnow A. Wurl P. MDM2 SNP309 associates with accelerated pancreatic adenocarcinoma formation. Pancreas. 2010;39:76-80.

24. Zhang X, Miao X, Guo Y, Tan W, Zhou Y, Sun T, et al. Genetic polymorphisms in cell cycle regulatory gene MDM2 and TP53 are associated with susceptibility to lung cancer Human mutation. 2006;27:110-7.

25. Li Y, Zhao H, Sun L, Huang L, Yang Q, Kong B, et al. MDM2 SNP309 is associated with endometrial cancer susceptibility: a meta-analysis. Hum Cell. 2011;24:57-64.

26. Marcel V, Palmero EI, Falagan-Lotsch P, Martel-Planche G, Ashton-Prolla P, Olivier M, et al. TP53 PIN3 and MDM2 SNP309 polymorphisms as genetic modifiers in the Li-Fraumeni syndrome: impact on age at first diagnosis. J Med Genet. 2009;46:766-72.

27. Oliner JD, Kinzler KW, Meltzer PS, George DL, Vogelstein B. Amplification of a gene encoding a p53associated protein in human sarcomas. Nature. 1992;358:80-3.

28. Hu Z, Jin G, Wang L, Chen F, Wang X, Shen h. MDM2 promoter polymorphism SNP309 contributes to tumor susceptibility: evidence from 21 case-control studies. Cancer Epidemiol Biomarkers Prev. 2007;16:2717-23.

29. Economopoulos KP, Sergentanis TN. Differential effects of MDM2 SNP309 polymorphism on breast cancer risk along with race: a meta-analysis. Breast Cancer Res Treat. 2010;120: 211-6.

30. Ho SM. Estrogen, progesterone and epithelial ovarian cancer. Reprod Biol Endocrinol. 2003;7:73. Review.

31. Zhang Y, Coogan, Palmer JR, Strom BL, Rosenberg L. Cigarette Smoking and Increased Risk of Mucinous Epithelial Ovarian Cancer. Am J Epidemiol. 2004;159:133-9.

32. Kelemen LE, Bandera EV, Terry KL, Rossing MA, Brinton LA, Doherty JA, et al. Recent alcohol consumption and risk of incident ovarian carcinoma: a pooled analysis of 5,342 cases and 10,358 controls from the Ovarian Cancer Association Consortium. BMC Cancer. 2013;13:1-12.

33. Stavropoulou AV, Fostira F, Pertesi M, Tsitlaidou M, Voutsinas GE, Triantafyllidou O, et al. Prevalence of BRCA1 Mutations in Familial and Sporadic Greek Ovarian Cancer Cases. PLoS One. 2013;8:e58182.

34. Sing CF and Rothman ED. A consideration of the chisquare test of Hardy-Weinberg equilibrium in a nonmultinomial situation. Ann. Hum. Genet. Lond. 1975;39:141-5.

35. Guo CY, Chen YJ, Chen YH. The logistic regression model for gene-environment interactions using both caseparent trios and unrelated case-controls. Ann Hum Genet. 2014;78:299-305. doi: 10.1111/ahg.12063.

36. Foretova L, Machackova E, Navratilova M, Pavlu H, Hruba M, Lukesova M, et al. BRCA1 and BRCA2 Mutations in Women With Familial or Early-onset Breast/Ovarian Cancer in the Czech Republic. Hum Mutat 2004;697:1-8. 
37. Bartel F, Jung J, Böhnke A, Gradhand E, Zeng K, Thomssen $\mathrm{C}$, et al. Both germ line and somatic genetics of the p53 pathway affect ovarian cancer incidence and survival. Clin Cancer Res. 2008;14:89-96.

38. Bond GL, Hirshfield KM, Kirchhoff T, Alexe G, Bond EE, Robins H, et al. MDM2 SNP309 accelerates tumor formation in a gender-specific and hormone-dependent manner. Cancer Res. 2006;66:5104-10.

39. Galic V, Willner J, Wollan M, Garg R, Garcia R, Goff BA, et al. Common polymorphisms in TP53 and MDM2 and the relationship to TP53 mutations and clinical outcomes in women with ovarian and peritoneal carcinomas. Genes Chromosomes Cancer. 2007;46:23947.

40. Jones JN, Hancock AR, Vogel H, Donehower LA, Branddy A. A overexpression of mice reveals a p53 independent role of mdm2 in tumorigenesis. Proc Natl Acad Sci USA. 1998;95:15608-12.
41. Dobbelstein M, Wienzek S, Koing C, Roth J. Inactivation of the p53 homologue p73 by the mdm2-oncoprotein. Oncogene. 1999;18:2101-6.

42. Freedman DA, Levine AJ. Regulation of p53 protein by MDM2 oncoprotein-thirty-eight G.H.A. Clowes memorial Award Lecture. Cancer Res. 1999;59:1-7.

How to cite this article: Takodara $S$, Dholariya $S$, Mir R, Saxena A. MDM2 promoter polymorphism (rs2279744) and serum estrogen level are associated with increased risk of epithelial ovarian cancer: A case-control study. Int J Clin Biochem Res. 2018;5(4):526-532. 